\title{
Gene therapy of pituitary diseases
}

\author{
Eun Jig Lee and J Larry Jameson \\ Endocrinology, Metabolism, and Molecular Medicine, Northwestern University, Feinberg School of Medicine, Chicago, Illinois 60611, USA \\ (Requests for offprints should be addressed to J L Jameson; Email: ljameson@northwestern.edu)
}

\begin{abstract}
Despite a stuttering course, gene therapy continues to provide a potential treatment avenue for many human diseases, including cancer and various inherited disorders. Gene therapy is also attractive for the treatment of local, benign disorders, such as pituitary adenomas. Advances in technology have focused on modifying existing viral vec-
\end{abstract}

tors and developing targeted expression of therapeutic genes in an effort to achieve efficacy with minimal toxicity. Gene therapy also offers innovative strategies for treating hypopituitarism by replacing hormones such as growth hormone $(\mathrm{GH})$ and vasopressin.

Journal of Endocrinology (2005) 185, 353-362

\section{Introduction}

The concept of gene therapy was originally introduced to treat inherited genetic disorders with the goal of replacing the defective gene with a normal one in diseased cells. This early concept has rapidly switched to a broader vision of gene therapy that uses genetic materials to alter the disease process. Currently, clinical trials are ongoing to examine the use of gene therapy in life-threatening diseases, such as malignant tumors and inherited genetic disorders.

Gene therapy for endocrine disorders, including pituitary diseases, is still at an early stage. Although a variety of pre-clinical models have been examined, there have been no attempts to use gene therapy for the treatment of pituitary diseases in humans. Pituitary cells are highly specialized and express a restricted profile of transcription factors, receptors, and hormones. For example, the anterior pituitary has five highly differentiated cell types: somatotropes (growth hormone $(\mathrm{GH})$ ), lactotropes (prolactin, (PRL)), corticotropes (adrenocorticotropin (ACTH)), gonadotropes (luteinizing hormone (LH) and follicle stimulating hormone (FSH)), and thyrotropes (thyroid stimulating hormone (TSH)). The posterior pituitary is a neural extension of the hypothalamus, and stores and secretes arginine vasopressin (AVP) and oxytocin. These highly-specialized features of pituitary cells afford a unique opportunity to develop targeted expression of therapeutic genes using cell type-specific approaches. Potential therapeutic targets include hormone overproduction by adenomas and hormone deficiency caused by primary pituitary or secondary hypothalamic disorders (Table 1).

In this review, we describe some of the strategies for approaching pituitary gene therapy and discuss the limitations and future directions of current approaches.

\section{Current treatment for pituitary adenomas}

Current therapies for pituitary tumors include surgery, radiotherapy, and pharmacological approaches for a subset of tumor types. For microadenomas $(<1 \mathrm{~cm})$, transsphenoidal surgery is successful in the majority of cases (70$90 \%$ ) in the hands of an experienced surgeon. However, larger macroadenomas are rarely cured by surgery alone (Lee \& Jameson 1997, Melmed 1997). Medical therapies are available for selected types of pituitary tumors. In the case of prolactinomas, dopamine agonists markedly reduce hormone secretion and reduce tumor size in most patients (Schlechte 1997). However, dopamine agonists do not cure the tumors, and they recur if the medications are discontinued. Somatostatin analogues are used for the treatment of growth hormone-secreting adenomas (Melmed et al. 2002) and for TSH-secreting adenomas (Lee et al. 1994, Beck-Peccoz \& Persani 2002). Finally, radiotherapy is used as an adjunctive treatment after surgery and, in rare instances, as primary treatment for pituitary tumors. Although radiotherapy is often effective, several years are usually required before it has full impact and potential complications include hypopituitarism, 
Table 1 Causes of pituitary diseases

\author{
Hormone excess \\ Pituitary tumors: GH, PRL, ACTH, LH/FSH, TSH \\ Hypothalamic or peripheral tumors: $\mathrm{GHRH}, \mathrm{CRH}$ \\ Hormone deficiency (pituitary hormone deficiency) \\ Idiopathic and congenital \\ Pituitary tumors \\ Pituitary apoplexy \\ Hypophysitis, vascular diseases, trauma \\ Hypothalamic releasing hormone deficiency \\ Kallman's syndrome \\ Primary or metastatic tumors \\ Head trauma \\ Inflammation \\ Vascular lesions
}

Mutation in genes encoding pituitary hormones, transcription factors, or receptors

$\mathrm{GH}$, growth hormone; PRL, prolactin; $\mathrm{ACTH}$, adenocorticotropin; LH, lutenizing hormone;

$\mathrm{FSH}$, follicle stimulating hormone; TSH, thyroid stimulating hormone; GHRH, GH releasing hormone;

$\mathrm{CRH}$, corticotropin releasing hormone.

secondary tumors and, occasionally, neural deficits (Melmed 1997).

\section{Gene therapy strategies for treating pituitary adenomas}

Gene therapy is a seemingly reasonable strategy for the treatment of pituitary tumors. Pituitary adenomas are biologically benign, relatively localized, and they rarely metastasize. Therefore, direct administration of therapeutic vectors has a greater chance of reaching most of the tumor cells. Partial efficacy, in the absence of complete destruction of all tumor cells, might be of clinical benefit either because of reduced tumor mass or because hormone levels can be lowered. In addition, determination of hormone levels can provide a quantitative means to assess residual tumor function. As described below, the specialized nature of pituitary cells offers the opportunity to use targeted expression of therapeutic genes to the pituitary tumor mass with limited or absent expression in nontumor cells, thereby minimizing toxicity. Key elements in the design of these approaches include the type of vector used to deliver the therapeutic gene, the type of promoter used to direct expression of the therapeutic gene and the type of therapeutic gene used to kill the tumor cells.

\section{Viral vectors}

Progress in recombinant DNA technology has made the delivery of foreign genes into normal or diseased cells a common reality. Both viral and nonviral delivery systems have been under development. Viral vectors include adenovirus, retrovirus, adeno-associated virus (AAV), lentivirus, and herpes simplex virus (HSV). Among these, adenovirus has been used most commonly for gene therapy. Adenoviruses are relatively easy to propagate and manipulate and they have a broad host range in vitro and in vivo. They have a large genome $(\sim 36 \mathrm{~kb})$, which allows them to carry relatively large, or multiple, foreign genes. Because adenoviruses do not integrate into the host cell genome, the foreign genes delivered by adenoviral vectors are expressed in an epichromosomal manner, and therefore have low genotoxicity for host cells (Horwitz 1990, Graham \& Prevec 1991, Ali et al. 1994). Because adenoviruses are expressed transiently, they are well-suited to cancer gene therapy where the goal is to destroy abnormal tissue as opposed to achieving long-term expression (as for factor IX or cystic fibrosis transmembrane conductance regulator (CFTR)). A large number of preclinical studies and clinical trials have been performed using adenoviral vectors in the treatment of malignant tumors (Kirn 2001a,b, Nemunaitis et al. 2001, Reid et al. 2001, Hamid et al. 2003, Vecil \& Lang 2003). They have also been used successfully for gene transfer into normal or tumorous animal pituitary cells (Castro et al. 1997, Lee et al. 1999, 2000, Davis et al. 2001).

Despite the advantages of adenoviruses, several features limit their use in the clinical setting. These include cytotoxicity (particularly hepatoxicity), induction of immune responses, and the potential for recombination in vivo (Jolly 1994). Tissue tropism of the adenovirus is another limitation, particularly when one wishes to achieve tissue-specific effects and to minimize toxicity (Huard et al. 1995). Intravascular or inhaled administration of adenoviral vectors results in a high level of gene transfer to the liver and respiratory tract, respectively, but other targets such as the pituitary gland are not infected efficiently. Several approaches might be used in an attempt to circumvent this problem. Direct administration of adenoviral vectors into a specific organ or tissue can result in efficient infection and a high level of transgene 
Table 2 Gene therapy for pituitary tumor

\author{
Vectors systems \\ Nonviral vectors: liposome for GH3 cell (in vitro) \\ Viral vectors: adenovirus, AAV, HSV, retrovirus, lentivirus \\ Therapeutic genes \\ Enzyme/prodrug: HSV-TK \\ Strong toxin: diphtheria toxin A \\ Tumor suppressor gene: RB \\ Growth inhibitors: dominant negative ER in $\mathrm{GH} 4$ lactotrope tumor \\ P16/CDKN2A in AtT20 tumor cells \\ Others: tyrosine hydroxylase

\section{Targeting strategies} \\ Transductional targeting: fiber modification of adenovirus \\ Transcriptional targeting: cell-specific promoters e.g. GH, PRL, GPH $\alpha$ ACTH (POMC); \\ inducible promoters e.g. tetracycline combined with PRL promoter, Cre-LoxP strategy
}

$\mathrm{AAV}$, adenoassociate virus; HSV, herpes simplex virus; HSV-TK, HSV-thymidine kinase;

$\mathrm{RB}$, retinoblastoma; $\mathrm{ER}$, estrogen receptor; $\mathrm{GPH} \alpha$, glycoprotein hormone $\alpha$-subunit;

$\mathrm{POMC}$, proopiomelanocortin.

expression (Acsadi et al. 1996, Riley et al. 1996). Injection into the carotid artery is not sufficient to convey preferential expression in the pituitary gland, presumably because of rapid dilution of the virus and entry into the general circulation (Lee et al. 2000). Although it remains possible that better vascular access could improve viral delivery, this is likely to be technically difficult and variable in its efficacy. On the other hand, stereotactic injection directly into the pituitary gland results in selective expression in the pituitary with a low level of infection in other organ such as the liver. However, with a ubiquitous promoter, such as cytomegalovirus (CMV), this approach does not preclude expression in other cell types. For this reason, additional strategies for achieving pituitary cell-specific expression have been developed (Lee et al. 2000, Davis et al. 2001).

\section{Targeted expression strategies}

Three main approaches have been used to achieve cellspecific expression in pituitary cells: (1) direct injection of viruses into the pituitary, (2) the use of pituitary hormone promoters, such as $\mathrm{GH}$, proopiomelanocortin (POMC), PRL, or glycoprotein hormone $\alpha$-subunit $(\mathrm{GPH} \alpha)$ to direct gene expression and (3) the use of Cre-mediated recombination to activate repressed promoters in a cellspecific manner. Examples of each of these strategies are described below as pre-clinical models of pituitary tumor gene therapy. In addition to selective expression in the pituitary, it is equally important to restrict expression in tissues like the liver, which are infected with very high efficiency, to minimize toxicity from viruses designed to carry suicide genes such as thymidine kinase.

In principle, it would be desirable to ultimately modify the tissue tropism of adenoviral vectors by changing their surface charge (Schwarzenberger et al. 1996) or by performing genetic modifications (Wickham et al. 1995, 1997, Krasnykh et al. 1996). For example, the natural tropism mediated by the adenoviral fiber coat protein altered to re-target adenoviral vectors to endothelial, smooth muscle, fibroblast, and macrophage cells (Wickham et al. 1995, Wickham et al. 1997). Thus, it may be possible, using genetic modifications, to insert $\mathrm{GH}$ secretogogues, somatostatin, or other small molecules on the adenoviral fiber to further restrict transgene expression to the pituitary.

\section{Therapeutic toxic genes}

A variety of therapeutic genes have been developed for cancer gene therapy. These include suicide gene/ prodrugs, apoptosis inducers, cytokines, and strong toxic genes (Table 2). A number of suicide gene/prodrug systems were identified and are currently being used in clinical trials and preclinical studies (Morris et al. 1999). The suicide gene encodes an enzyme, usually of viral or prokaryotic origin, that is capable of converting an otherwise nontoxic prodrug into an active toxin that causes cell death. The commonly used genes that activate prodrugs include the herpes simplex virus-1 thymidine kinase (HSV-TK) gene, the Escherichia coli nitroreductase gene, the Escherichia coli cytosine deaminase gene, and Escherichia coli guanine phosphoribosyltransferase. Apoptosis-inducing genes are also likely to be good candidates for gene therapy of pituitary tumors. These include genes encoding p53, retinoblastoma (RB), dominant negative forms of growth factors, antiangiogenic factors, Fas ligand, Bax, Bcl-Xs, and caspases.

The HSV-TK gene has been used most commonly as a suicide gene/prodrug system. The cytotoxic effects of the HSV-TK gene can be activated by treatment with synthetic nucleosides such as acyclovir (ACV) or ganciclovir 
(GCV) (Morris et al. 1999). In the setting of cancer gene therapy, GCV is usually used because it is more effective and less toxic than ACV (Elion 1982, Biron et al. 1985). GCV is monophosphorylated by HSV-TK. An endogenous cellular kinase rapidly catalyzes subsequent phosphorylation steps (Miller \& Miller 1980, 1982), leading to production of the GCV triphosphate (GCV-TP). GCV-TP is highly toxic to proliferating mammalian cells. The incorporation of the false nucleotide results in basepair mismatches, DNA fragmentation, sister chromatid exchange, and lethal genome instability (Haynes et al. 1996). In addition, GCV inhibits cellular DNA polymerases and thereby further blocks DNA synthesis (Ilsley et al. 1995). One of the benefits of using thymidine kinase as a toxic gene is its ability to generate a bystander effect, for example, it has been shown that complete regression of tumors can be observed when only $10 \%$ of the tumor cells express thymidine kinase (Moolten 1986). This effect reflects the fact that GCV-TP can be transferred from HSV-TK positive cells to the untransduced cells through gap junctions. Cell-to-cell contact is therefore required for the bystander effect.

Recombinant viral vectors carrying suicide genes such as HSV-TK can be readily generated because they are nontoxic or minimally toxic to viral packaging cell lines, even when expressed. However, the generation of a viral vector carrying a highly toxic gene such as a diphtheria toxin is challenging, even if the toxic gene is driven by a cell-specific promoter, as nonspecific expression of even a few molecules kills the packaging cell line during generation of the recombinant viral vectors. The Cre-loxP recombinase system (see below) may afford a solution to this problem by providing a strategy to preempt the expression of the toxic gene during generation of the vector.

\section{Preclinical models for gene therapy of pituitary tumors}

Preclinical gene therapy models for the treatment of pituitary tumors have primarily used adenoviruses as vectors for gene delivery (Table 2) (Riley et al. 1996, Castro et al. 1997, Lee et al. 1999, 2000, 2001a,b,c,d, Southgate et al. 2000, Windeatt et al. 2000, Davis et al. 2001, Smith-Arica et al. 2001, Southgate et al. 2001, Williams et al. 2001, Lee \& Jameson 2002). In the first pituitary gene therapy model, Castro et al. (1997) demonstrated high levels of $\beta$-galactosidase gene expression in normal and tumorous (GH3 and AtT20) pituitary cells using an adenovirus carrying the $\beta$-galactosidase gene driven by ubiquitously active viral promoters. This study suggested the feasibility of using adenoviral vectors to deliver cytotoxic gene therapy to pituitary tumors. The earliest in vivo animal model used adenovirus-mediated retinoblastoma $(\mathrm{Rb})$ gene therapy in spontaneous pituitary melanotrope tumors in Rb-deficient mice (Riley et al. 1996). Intratumoral RB cDNA gene delivery inhibited tumor growth and prolonged the life span of treated animals.

In subsequent studies, HSV-TK gene delivery has been most commonly used in rodent models bearing pituitary tumors implanted intradermally in nude mice or in estrogen-induced pituitary tumors in rats. The HSV-TK system has the advantage that the pro-drug activation is partially reversible by withdrawing GCV. The adenoviral vectors contain the HSV-TK gene driven by either pituitary hormone-specific promoters (GH, PRL, GPH $\alpha$, and POMC) or the ubiquitously expressed CMV promoter (Lee et al. 1999, 2001c, Southgate et al. 2000, Windeatt et al. 2000). In studies using nude mice bearing pituitary tumors (GH or ACTH), GCV treatment after intratumoral injection of the adenoviral vectors containing the HSV-TK gene was highly effective, preventing further growth and destroying existing tumor cells. This apparent success may be due in part to the rapidly growing nature of pituitary tumor cell lines in nude mice and the bystander effect of HSV-TK. In contrast, a recent study found that the HSV-TK/GCV system under the control of the human prolactin promoter was not effective in suppressing prolactin levels in a rat model of lactotropehyperplasia (Southgate et al. 2000). This model may more closely resemble human pituitary tumors, which normally grow very slowly. However, the expression of HSV-TK by CMV promoter was effective in the same animal model (Windeatt et al. 2000), suggesting that benign pituitary adenomas might be less sensitive to the HSV-TK system unless it is expressed by a strong promoter. It should be noted, however, that high generalized expression of the TK gene product with GCV treatment may induce deleterious effects on adjacent normal pituitary cells through a bystander effect. Delivery of apoptosis-inducing or directly toxic genes may therefore be more effective for slow growing tumors.

The Cre-loxP approach has two potential advantages: (1) it facilitates the production of adenoviruses carrying highly toxic genes by allowing reversible repression of promoters and (2) it provides a strategy for combinatorial activation of toxic gene expression, providing additional specificity by using separate cell-specific promoters to drive Cre expression and toxic gene expression. The Cre-loxP strategy takes advantage of the excisional deletion and recombination of a DNA sequence flanked by a pair of loxP sites, the Cre-specific recognition sequence of 34 nucleotides. A recombinant adenovirus carrying the cre recombinase gene has recently been developed and used to activate or inactivate a transgene in eukaryotic cells (Anton \& Graham 1995, Sato et al. 1998a, Sato et al. 1998b, Piston et al. 1999) and animals (Stec et al. 1999). Using the Cre-loxP strategy, a two-component recombinant adenoviral system was recently developed to allow regulated activation of diphtheria toxin gene (Fig. 1) (Lee \& Jameson 2002). 


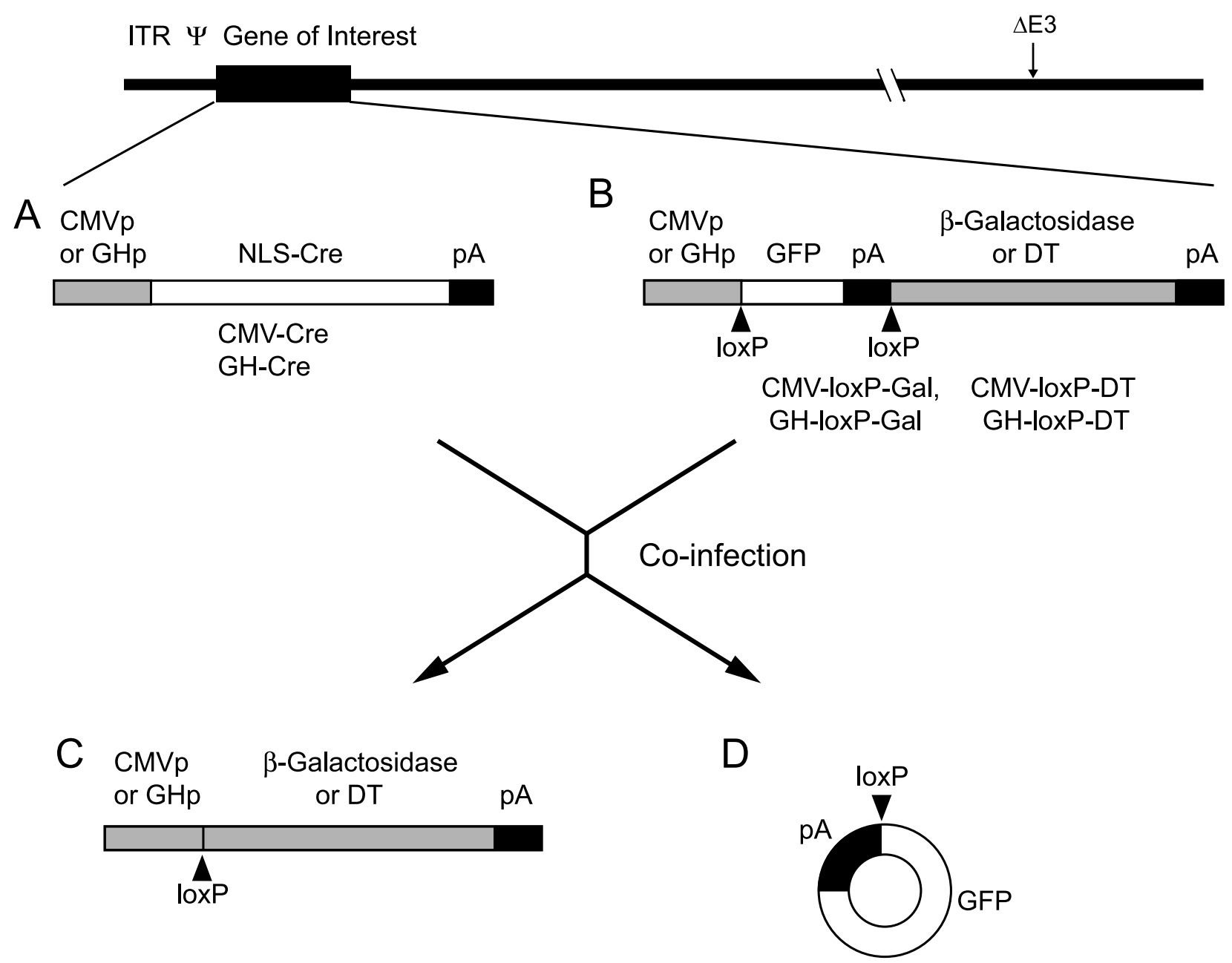

Figure 1 Structure of recombinant adenoviral vectors and co-infection strategy. (A) Adenoviral vectors (CMV-Cre and GH-Cre) carrying the Cre recombinase gene controlled by the cytomegalovirus (CMV) promoter or the human GH promoter. (B) Adenoviral vectors (CMV-loxP-Gal, GH-loxP-Gal, CMV-loxP-DT and GH-loxP-DT) carrying the $\beta$-galactosidase gene or the DT gene. The GFP gene with an additional poly (A) signal flanked by a pair of loxP sequences was placed between the promoter and cDNA. (C, D) After co-infection of $\mathrm{A}$ and $\mathrm{B}$, Cre recombinase excises GFP and poly $(\mathrm{A})$ and recombines the promoter with the $\beta$-galactosidase or DT genes, activating their expression. ITR, inverted terminal repeat; $\Psi$, packaging signal sequences; E1, early region 1; E3, early region 3; NLS, nuclear localized signal; DT, diphtheria toxin; pA, poly (A). (reprinted from Lee \& Jameson 2002, with permission).

The first component contains a transcriptional blocking sequence flanked by loxP sites, interposed between the promoter and the cDNA for diphtheria toxin or a marker gene. In the second vector, Cre recombinase is driven by a cell type-specific promoter. Using co-infection of two adenoviral vectors, the marker or toxic gene was successfully activated in GH producing pituitary tumor cells in vitro and in vivo. These results indicate that Cre-mediated activation of a loxP-repressed form of the diptheria toxin (DT) gene provides a useful strategy for targeted suicide gene therapy for pituitary tumors. Diphtheria toxin-A segment (DT-A) exhibits no bystander effect, as it is unable to cross cell membranes. This feature could be advantageous in comparison to the HSV-TK/
GCV system, as it might achieve selective killing of pituitary adenoma cells without harmful effects on adjacent tissues or normal pituitary cells.

Prolactinomas are estrogen-dependent tumors and express estrogen receptors (ER) (Chaidarun et al. 1998, Shupnik et al. 1998). Antiestrogens including ICI 164384 and ICI 182780 have been shown to down-regulate ER, and effectively inhibit growth of pituitary GH3 cells (Newton 1995). Dominant negative forms of the ER have been suggested as an alternative method to inactivate the ER. Several dominant negative ER mutants have been reported, including truncated receptors (ER1-530 and ER1-536, missing the last 65 or 59 amino acid residues), a point mutant (L540Q), and a frame shift mutant (S554fs) 
(Ince et al. 1993, 1995, Chien et al. 1999, Lazennec et al. 1999). Adenovirus-mediated expression of ER1-536 or L540Q suppressed proliferation of pituitary lactotrope GH4C1 cells in vitro and in vivo (Lee et al. 2001b). Thus, it may be possible to consider expression of specific biologic modifier genes as well as more generally toxic genes. In this context, an interesting model involves delivery of the tyrosine hydroxylase $(\mathrm{TH})$ gene for the treatment of prolactin-producing pituitary tumors (Freese et al. 1996). Dopamine (D2) receptor agonists are known to be effective for treating most prolactinomas. The TH gene encodes the rate-limiting enzyme in dopamine synthesis. The overexpression of the $\mathrm{TH}$ gene by adenovirus-mediated gene delivery suppressed prolactin levels and tumor growth in an estrogen/sirpiride-induced pituitary tumor model in rats (Williams et al. 2001).

A recent study demonstrated cell-specific expression of a marker gene in sheep after stereotactic injection of adenoviral vectors. This experiment was designed to establish a larger animal model, and extended similar approaches performed previously in rodents. In this experiment, the PRL promoter driven $\beta$-galactosidase achieved cell-specific expression with maintenance of normal endocrine function for a short period of time (Davis et al. 2001). However, there hypophysitis associated with lymphocytic infiltration and periglandular fibrosis developed during the first 7 days after adenoviral injection (Davis et al. 2002). Although a severe pituitary inflammatory reaction has not been seen in previous rodent studies, this result indicates the need for careful evaluation of the safety of gene therapy before being applied to humans. These findings also emphasize the need to explore means to reduce the immune responsiveness to adenoviruses.

\section{Gene therapy strategies for treating pituitary insufficiency}

\section{Vector considerations for long-term hormone replacement}

Long-term expression of a therapeutic gene is required for the gene therapy of pituitary insufficiency. Ideally, the gene therapy approach should also achieve regulated pituitary hormone secretion. In order to fulfill these goals, one must consider the optimal method of gene delivery, as well as the how to regulate expression. Ex vivo and in vivo strategies have been considered, the ex vivo approach involves the generation of hormone-producing cells by introducing therapeutic genes into cells from the patient and then reintroducing cells into the patient, this approach can minimize immune response. The in vivo approach requires direct administration of the vector containing therapeutic genes. Candidate vectors for in vivo delivery include: adeno-associated virus (AAV), gutted adenovirus, lentivirus, and HSV-1. AAV-2, one of the members of the Parvoviridae family, is nonpathogenic in humans and its genome integrates into human chromosomal DNA in a specific manner. Thus, the nonpathogenic nature of AAV-2, coupled with site-specific integration, provides sufficient merit to consider recombinant AAV vectors for gene therapy of pituitary insufficiency, although the packaging capacity of this vector is limited $(<4.5 \mathrm{~kb})$ (Carter \& Samulski 2000, Rabinowitz \& Samulski 2000, Buning et al. 2003).

One of the recent advances in adenoviral vector development is the use of a gutted adenoviral vector, the so called the helper-dependent (HD) system (Schiedner et al. 1998). In this vector system, the coding sequence of the adenoviral genome is completely deleted, retaining only the inverted terminal repeats (ITRs) and packaging signal sequences, which are the only essential cis-elements required for viral replication and packaging. The deleted genome is replaced with foreign DNA fragments containing the expression cassette and stuffer sequences. In order for this viral genome to be propagated and rescued in a viral particle, the proteins necessary for viral replication and packaging are needed from a helper virus. The advantage of this system is low immunogenicity, longterm gene expression, and a high packaging capacity (up to $35 \mathrm{~kb}$ ). However, helper virus contamination is still an issue, especially for large-scale production.

Lentiviral vectors, derived from the human immunodeficiency virus (HIV), have the potential for genome integration. They can infect dividing and non-dividing cells, which is advantageous relative to existing retroviral vectors, that can only integrate into dividing cells. Currently, a gutted third generation lentiviral vector system is available (Dull et al. 1998, Zufferey et al. 1998), but its application in humans remains unproven.

HSV-1 has recently emerged as a gene therapy vector and has been exploited for gene transduction into the central nervous system. HSV-1 can persist in a latent state in neurons. Recent techniques have improved the manipulation of the large HSV genome $(-150 \mathrm{~kb})$ and removed the need for a helper virus. HSV-mediated marker gene expression has also been demonstrated in normal and tumorous pituitary cells in vitro and in vivo (Bolognani et al. 2001). Therefore, this vector may be a realistic option for targeted gene expression in the hypothalamus.

\section{GH replacement approaches}

Recombinant human GH (hGH) is the current treatment of choice for $\mathrm{GH}$ deficient patients. Recombinant hGH promotes linear growth in $\mathrm{GH}$ deficient children (Wyatt 2004) and it increases muscle mass and reduces adipose tissue in GH deficient adults (Hull \& Harvey 2003, Merriam et al. 2004). However, the inconvenience caused by daily injections and the occasional development of anti-GH antibodies has led to consideration of a gene therapy approach (Ahangari et al. 2004). Because the targets of $\mathrm{GH}$ are peripheral organs, $\mathrm{GH}$ gene therapy does 
Table 3 Gene therapy for pituitary insufficiency

\begin{tabular}{|c|c|c|}
\hline Therapeutic genes & Vectors & Condition \\
\hline \multicolumn{3}{|l|}{ Receptor gene } \\
\hline GHRH receptor & Adenovirus & In vitro $\mathrm{GH} 3$ cells \\
\hline \multicolumn{3}{|l|}{ Hormone gene } \\
\hline $\mathrm{GH}$ & Cationic liposome & In vitro muscle cells \\
\hline $\mathrm{GH}$ & Engineered myocytes & In vivo dwarf mouse \\
\hline $\mathrm{GH}$ & Engineered $2 \mathrm{Y} 1$ cells & In vivo rat \\
\hline $\mathrm{GH}$ & Engineered autologous BM stromal cells & Ex vivo \\
\hline \multicolumn{3}{|l|}{ Hypothalamic gene } \\
\hline \multirow[t]{3}{*}{ AVP } & Adenovirus & AVP deficient Brattleboro rat \\
\hline & AAV & AVP deficient Brattleboro rat \\
\hline & Lentivirus & AVP deficient Brattleboro rat \\
\hline
\end{tabular}

not necessarily need to be pituitary-specific. However, $\mathrm{GH}$ is secreted in a pulsatile fashion and has a distinct circadian rhythm that is modulated by sleep, meals, and activity. Thus, gene therapy should ideally achieve not only the restoration of normal gene expression, but also strict control of physiologic GH secretion. These are challenging goals.

The earliest approach for GH gene therapy involved the in vitro generation of $\mathrm{GH}$-producing cells using myoblasts (Dhawan et al. 1991, MacColl et al. 2000), fibroblasts (Heartlein et al. 1994), or 2 Y1 cells (Inazawa et al. 2001) with implantation into animals with GH deficiency. In order to minimize the host immune response, microencapsulation was employed and $\mathrm{GH}$ production was maintained for up to 6 months (Al-Hendy et al. 1995, 1996). In another ex-vivo approach, autologous bone marrow stromal cells were engineered to produce $\mathrm{GH}$, and then transplanted back into dogs (Hurwitz et al. 1997). Because the liver synthesizes insulin like growth factor-1 (IGF-1) in response to GH, adenoviruses have been used to targeted $\mathrm{GH}$ expression in $\mathrm{GH}$ deficient lit/lit mice. Treated mice show an elevation of serum GH and IGF-1, with restoration of normal growth and weight gain (Hahn et al. 1996).

All of the approaches described above are limited by the absence of an appropriate means for regulating gene expression. Although recent attempts have included the use regulatable or tissue-specific promoters, physiologic GH secretion and production has not been fully achieved. The generation of hormone-producing cells from stem cells may provide a better solution. For example, insulin-producing cells have been produced in mouse liver after adenoviralmediated delivery of islet-specific transcription factors (Ferber et al. 2000, Kojima et al. 2003). These insulinproducing cells appear to differentiate from progenitor cells after the introduction of $\beta$-cell lineage-specific transcription factors. These cells secrete insulin in response to blood glucose elevation. Induction of differentiation from progenitor cells using pituitary lineage specific transcription factors could provide an alternate strategy for somatotrope neogenesis, for this approach Pit-1 or PROP-1 are candidate genes. Indeed, the strategy of combining gene therapy with cellular therapy offers unique prospects for hormonal and tissue replacement (Bodine et al. 2005).

\section{Vasopressin replacement approaches}

Central diabetes insipidus is caused by the absence of synthesis or secretion of AVP from neurohypophysis. The most common cause of AVP deficiency is the destruction of the neurohypophyseal neurons and axons secondary to pituitary or hypothalamic tumors, infection, trauma, or surgical procedures. There are also rare congenital and familial forms of vasopressin deficiency. Missense and nonsense mutations in AVP neurophysin II gene cause familial neurohypophyseal diabetes insipidus (FNDI) (Ito et al. 1991, Nagasaki et al. 1995, Boson et al. 2003). While synthetic vasopressin is available and is relatively easy to administer, replacement of the AVP gene is a theoretical option for patients with central diabetes inspidus (DI). Because AVP is released by osmotic control systems, AVP gene expression should be targeted to the supraoptic nucleus (SON) or paraventricular nucleus (PVN), which receives neural input from osmoreceptors.

The AVP gene has been delivered by adenovirus to the hypothalamus of the Brattleboro rat, an AVP deficient animal model of central DI (Geddes et al. 1997), AAV (Ideno et al. 2003), or lentivirus (Bienemann et al. 2003). AVP production was documented and resulted in reduced water intake and urine volume, as well as increased urine osmolality from 4 months to 1 year. Recently, a mouse model for autosomal dominant human FNDI was established (Russell et al. 2003), providing another model for gene therapy approaches for vasopressin deficiency.

\section{References}

Acsadi G, Lochmuller H, Jani A, Huard J, Massie B, Prescott S, Simoneau M, Petrof BJ \& Karpati G 1996 Dystrophin expression in 
muscles of mdx mice after adenovirus-mediated in vivo gene transfer. Human Gene Therapy 7 129-140.

Ahangari G, Ostadali MR, Rabani A, Rashidian J, Sanati MH \& Zarindast MR 2004 Growth hormone antibodies formation in patients treated with recombinant human growth hormone. International Journal of Immunopathology and Pharmacology 17 33-38.

Al-Hendy A, Hortelano G, Tannenbaum GS \& Chang PL 1995 Correction of the growth defect in dwarf mice with nonautologous microencapsulated myoblasts-an alternate approach to somatic gene therapy. Human Gene Therapy 6 165-175.

Al-Hendy A, Hortelano G, Tannenbaum GS \& Chang PL 1996 Growth retardation-an unexpected outcome from growth hormone gene therapy in normal mice with microencapsulated myoblasts. Human Gene Therapy 7 61-70.

Ali M, Lemonine N \& Ring CJA 1994 The use of DNA viruses as vectors for gene therapy. Gene Therapy 1 367-384.

Anton M \& Graham FL 1995 Site-specific recombination mediated by an adenovirus vector expressing the cre recombinase protein: a molecular switch for control of gene expression. Journal of Virology 69 4600-4606.

Beck-Peccoz P \& Persani L 2002 Medical management of thyrotropin-secreting pituitary adenomas. Pituitary $\mathbf{5} 83-88$.

Bienemann AS, Martin-Rendon E, Cosgrave AS, Glover CP, Wong LF, Kingsman SM, Mitrophanous KA, Mazarakis ND \& Uney JB 2003 Long-term replacement of a mutated nonfunctional CNS gene: reversal of hypothalamic diabetes insipidus using an EIAV-based lentiviral vector expressing arginine vasopressin. Molecular Therapy 7 588-596.

Biron KK, Stanat SC, Sorrell JB, Fyfe JA, Keller PM, Lambe CU \& Nelson DJ 1985 Metabolic activation of the nucleoside analog 9-[(2-hyroxy-1-(hydroxymethyl)ethoxy] methyl)guanine in human diploid fibroblasts infected with human cytomegalovirus. PNAS $\mathbf{8 2}$ 2473-2477.

Bodine D, Jameson JL \& McKay R 2005 Stem cell and gene transfer in clinical medicine. In Harrison's Principles of Internal Medicine, edn 16, pp 392-397. Eds DL Kasper, E Braunwald, AS Fauci, SL Hauser, DL Longo \& JL Jameson. New York: McGraw-Hill Companies, Inc.

Bolognani F, Albarino C, Romanowski V, Carri NG \& Goya RG $2001 \mathrm{In}$ vitro and in vivo herpetic vector-mediated gene transfer in the pituitary gland: impact on hormone secretion. European Journal of Endocrinology 145 497-503.

Boson WL, Sarubi JC, d'Alva CB, Friedman E, Faria D, De Marco L \& Wajchenberg B 2003 A signal peptide mutation of the arginine vasopressin gene in monozygotic twins. Clinical Endocrinology $\mathbf{5 8}$ 108-110.

Buning H, Nicklin SA, Perabo L, Hallek M \& Baker AH 2003 AAV-based gene transfer. Current Opinion in Molecular Therapy $\mathbf{5}$ 367-375.

Carter PJ \& Samulski RJ 2000 Adeno-associated viral vectors as gene delivery vehicles. International Journal of Molecular Medicine 6 17-27.

Castro MG, Goya RG, Sosa YE, Rowe J, Larregina A, Morelli A \& Lowenstein PR 1997 Expression of transgenes in normal and neoplastic anterior pituitary cells using recombinant adenoviruses: long term expression, cell cycle dependency, and effects on hormone secretion. Endocrinology 138 2184-2194.

Chaidarun SS, Swearingen B \& Alexander JM 1998 Differential expression of estrogen receptor-beta (ER beta) in human pituitary tumors: functional interactions with ER alpha and a tumor-specific splice variant. Journal of Clinical Endocrinology and Metabolism $\mathbf{8 3}$ 3308-3315.

Chien PY, Ito M, Park Y, Tagami T, Gehm BD \& Jameson JL 1999 A fusion protein of the estrogen receptor (ER) and nuclear receptor corepressor ( $\mathrm{NCoR}$ ) strongly inhibits estrogen-dependent responses in breast cancer cells. Molecular Endocrinology 13 2122-2136.

Davis JR, McVerry J, Lincoln GA, Windeatt S, Lowenstein PR, Castro MG \& McNeilly AS 2001 Cell type-specific adenoviral transgene expression in the intact ovine pituitary gland after stereotaxic delivery: an in vivo system for long- term multiple parameter evaluation of human pituitary gene therapy. Endocrinology 142 795-801.

Davis JR, McMahon RF, Lowenstein PR, Castro MG, Lincoln GA \& McNeilly AS 2002 Adenovirus-mediated gene transfer in the ovine pituitary gland is associated with hypophysitis. Journal of Endocrinology 173 265-271.

Dhawan J, Pan LC, Pavlath GK, Travis MA, Lanctot AM \& Blau HM 1991 Systemic delivery of human growth hormone by injection of genetically engineered myoblasts. Science $\mathbf{2 5 4}$ 1509-1512.

Dull T, Zufferey R, Kelly M, Mandel RJ, Nguyen M, Trono D \& Naldini L 1998 A third-generation lentivirus vector with a conditional packaging system. Journal of Virology 72 8463-8471.

Elion GB 1982 Mechanism of action and selectivity of acyclovir. American Journal of Medicine 73 7-13.

Ferber S, Halkin A, Cohen H, Ber I, Einav Y, Goldberg I, Barshack I, Seijffers R, Kopolovic J, Kaiser N et al. 2000 Pancreatic and duodenal homeobox gene 1 induces expression of insulin genes in liver and ameliorates streptozotocin-induced hyperglycemia. Nature Medicine 6 568-572.

Freese A, During MJ, Davidson BL, Gennarelli TA, Kaplitt MG, Flamm ES \& Snyder PJ 1996 Transfection of human lactotroph adenoma cells with an adenovirus vector expressing tyrosine hydroxylase decreases prolactin release. Journal of Clinical Endocrinology and Metabolism 81 2401-2404.

Geddes BJ, Harding TC, Lightman SL \& Uney JB 1997 Long-term gene therapy in the CNS: reversal of hypothalamic diabetes insipidus in the Brattleboro rat by using an adenovirus expressing arginine vasopressin. Nature Medicine 3 1402-1404.

Graham FL \& Prevec L 1991 Manupulation of adenovirus vectors. In Methods in Molecular Biology, pp 109-128. Ed. EJ Murray. Clifton, NJ: The Humana Press.

Hahn TM, Copeland KC \& Woo SL 1996 Phenotypic correction of dwarfism by constitutive expression of growth hormone. Endocrinology 137 4988-4993.

Hamid O, Varterasian ML, Wadler S, Hecht JR, Benson A 3rd, Galanis E, Uprichard M, Omer C, Bycott P, Hackman RC et al. 2003 Phase II trial of intravenous CI-1042 in patients with metastatic colorectal cancer. Journal of Clinical Oncology 21 $1498-1504$

Haynes P, Lambert TR \& Mitchell ID 1996 Comparative in-vivo genotoxicity of antiviral nucleotide analoques; penciclovir, ganciclovir and xanthine analogue, caffeine, in the mouse bone marrow micronucleus assay. Mutation Research 369 65-74.

Heartlein MW, Roman VA, Jiang JL, Sellers JW, Zuliani AM, Treco DA \& Selden RF 1994 Long-term production and delivery of human growth hormone in vivo. PNAS 91 10967-10971.

Horwitz MS 1990 Adenoviridae and their replication. In Virology, pp 1679-1721. Eds BN Fields, DM Knipe et al. [q;4 Can you give the names of the other editors?] New York: Raven Press.

Huard J, Lochmuller H, Acsadi G, Jani A, Massie B \& Karpati G 1995 The route of administration is a major determinant of the transduction efficiency of rat tissues by adenoviral recombinants. Gene Therapy 2 107-115.

Hull KL \& Harvey S 2003 Growth hormone therapy and Quality of Life: possibilities, pitfalls and mechanisms. Journal of Endocrinology 179 311-333.

Hurwitz DR, Kirchgesser M, Merrill W, Galanopoulos T, McGrath CA, Emami S, Hansen M, Cherington V, Appel JM, Bizinkauskas CB et al. 1997 Systemic delivery of human growth hormone or human factor IX in dogs by reintroduced genetically modified autologous bone marrow stromal cells. Human Gene Therapy $\mathbf{8}$ 137-156.

Ideno J, Mizukami H, Honda K, Okada T, Hanazono Y, Kume A, Saito T, Ishibashi S \& Ozawa K 2003 Persistent phenotypic 
correction of central diabetes insipidus using adeno-associated virus vector expressing arginine-vasopressin in Brattleboro rats. Molecular Therapy 8 895-902.

Ilsley DD, Lee SK, Miller WH \& Kuchta RD 1995 Acyclic guanosine analogs inhibiy DNA polymerase $\alpha, \beta$ and $\varepsilon$ with very different potencies and have unique mechanisms of action. Biochemistry 34 2504-2510.

Inazawa $\mathrm{T}$, Tanabe $\mathrm{T}$, Yamada $\mathrm{H}$, Nakaoka $\mathrm{T}$, Hashimoto $\mathrm{Y}$, Yamasaki T, Kotaki H, Tani K, Asano S \& Yamashita N 2001 Glucocorticoid-regulated expression of exogenous human growth hormone gene in rats. Molecular Therapy 4 267-272.

Ince BA, Zhuang Y, Wrenn CK, Shapiro DJ \& Katzenellenbogen BS 1993 Powerful dominant negative mutants of the human estrogen receptor. Journal of Biological Chemistry 268 14026-14032.

Ince BA, Schodin DJ, Shapiro DJ \& Katzenellenbogen BS 1995 Repression of endogenous estrogen receptor activity in MCF-7 human breast cancer cells by dominant negative estrogen receptors. Endocrinology 136 3194-3199.

Ito M, Mori Y, Oiso Y \& Saito H 1991 A single base substitution in the coding region for neurophysin II associated with familial central diabetes insipidus. Journal of Clinical Investigation 87 725-728.

Jolly D 1994 Viral vector systems for gene therapy. Cancer Gene Therapy 1 51-64.

Kirn D 2001a Oncolytic virotherapy for cancer with the adenovirus dl1520 (Onyx-015): results of phase I and II trials. Expert Opinion on Biological Therapy 1 525-538.

Kirn D $2001 b$ Clinical research results with d11520 (Onyx-015), a replication-selective adenovirus for the treatment of cancer: what have we learned? Gene Therapy 8 89-98.

Kojima H, Fujimiya M, Matsumura K, Younan P, Imaeda H, Maeda M \& Chan L 2003 NeuroD-betacellulin gene therapy induces islet neogenesis in the liver and reverses diabetes in mice. Nature Medicine 9 596-603.

Krasnykh VN, Mikheeva GV, Douglas JT \& Curiel DT 1996 Generation of recominant adenovirus vectors with modified fibers for altering viral tropism. Journal of Virology 70 6839-6846.

Lazennec G, Alcorn JL \& Katzenellenbogen BS 1999 Adenovirus-mediated delivery of a dominant negative estrogen receptor gene abrogates estrogen-stimulated gene expression and breast cancer cell proliferation. Molecular Endocrinology 13 969-980.

Lee EJ \& Jameson JL 1997 Gonadotropin (FSH and LH) pituitary tumors. In Disease of the pituitary. Diagnosis and treatment, pp 247-272. Ed. ME Wierman. Totowa: Humana Press Inc.

Lee EJ \& Jameson JL 2002 Cell-specific cre-mediated activation of the diphtheria toxin gene in pituitary tumor cells: potential for cytotoxic gene therapy. Human Gene Therapy 13 533-542.

Lee EJ, Kim KR, Lim SK, Lee HC, Kim DI, Kim SH \& Huh KB 1994 Reduction in size of a thyrotropin-secreting pituitary adenoma treated with octreotide acetate (somatostatin analog). European Journal of Endocrinology 131 109-112.

Lee EJ, Anderson LM, Thimmapaya B \& Jameson JL 1999 Targeted expression of toxic genes directed by pituitary hormone promoters: a potential strategy for adenovirus-mediated gene therapy of pituitary tumors. Journal of Clinical Endocrinology and Metabolism $\mathbf{8 4}$ 786-794.

Lee EJ, Thimmapaya B \& Jameson JL 2000 Stereotactic injection of adenoviral vectors that target gene expression to specific pituitary cell types: implications for gene therapy. Neurosurgery $\mathbf{4 6}$ 1461-1468; discussion 1468-1469.

Lee EJ, Duan WR, Kotlar T \& Jameson JL 2001a Restoration of growth hormone-releasing hormone $(\mathrm{GHRH})$ responsiveness in pituitary GH3 cells by adenovirus-directed expression of the human GHRH receptor. Endocrinology 142 414-420.

Lee EJ, Duan WR, Jakacka M, Gehm BD \& Jameson JL $2001 b$ Dominant negative ER induces apoptosis in $\mathrm{GH}(4)$ pituitary lactotrope cells and inhibits tumor growth in nude mice. Endocrinology 142 3756-3763.
Lee EJ, Martinson F, Kotlar T, Thimmapaya B \& Jameson JL 2001c Adenovirus-mediated targeted expression of toxic genes to adrenocorticotropin-producing pituitary tumors using the proopiomelanocortin promoter. Journal of Clinical Endocrinology and Metabolism 86 3400-3409.

Lee EJ, Jakacka M, Duan WR, Chien PY, Martinson F, Gehm BD \& Jameson JL 2001d Adenovirus-directed expression of dominant negative estrogen receptor induces apoptosis in breast cancer cells and regression of tumors in nude mice. Molecular Medicine 7 773-782.

MacColl GS, Novo FJ, Marshall NJ, Waters M, Goldspink G \& Bouloux PM 2000 Optimisation of growth hormone production by muscle cells using plasmid DNA. Journal of Endocrinology 165 329-336.

Melmed S 1997 General aspects of the management of pituitary tumors by surgery or radiation therapy. In Endocrinology, edn 3, pp 497-503. Ed. LJ DeGroot. Philadelphia: W.B. Saunders Co.

Melmed S, Vance ML, Barkan AL, Bengtsson BA, Kleinberg D, Klibanski A \& Trainer PJ 2002 Current status and future opportunities for controlling acromegaly. Pituitary 5 185-196.

Merriam GR, Carney C, Smith LC \& Kletke M 2004 Adult growth hormone deficiency: current trends in diagnosis and dosing. Journal of Pediatrics Endocrinology and Metabolism 17 Suppl 4 1307-1320.

Miller WH \& Miller RL 1980 Phosphorylation of acyclovir (acycloguanosine) monophosphate by GMP kinase. Journal of Biological Chemistry 255 7204-7207.

Miller WH \& Miller RL 1982 Phosphorylation of acyclovir diphosphate by cellular enzyme. Biochemical Pharmacology 31 3879-3884.

Moolten FL 1986 Tumor chemosensitivity conferred by inserted herpes thymidine kinase gene: paradigm for a prospective cancer control strategy. Cancer Research 46 5276-5281.

Morris JC, Touraine R, Wildner O \& Blaese RM 1999 Suicide genes: gene therapy applications using enzyme/prodrug strategies. In The Development of Human Gene Therapy, pp 477-526. Ed. T Friedmann. Cold Spring Harbor: Cold Spring Harbor Laboratory Press.

Nagasaki H, Ito M, Yuasa H, Saito H, Fukase M, Hamada K, Ishikawa E, Katakami H \& Oiso Y 1995 Two novel mutations in the coding region for neurophysin-II associated with familial central diabetes insipidus. Journal of Clinical Endocrinology and Metabolism $\mathbf{8 0}$ $1352-1356$.

Nemunaitis J, Khuri F, Ganly I, Arseneau J, Posner M, Vokes E, Kuhn J, McCarty T, Landers S, Blackburn A et al. 2001 Phase II trial of intratumoral administration of ONYX-015, a replication-selective adenovirus, in patients with refractory head and neck cancer. Journal of Clinical Oncology 19 289-298.

Newton CJ 1995 Estrogen receptor blockade by the pure antiestrogen, ZM 182780, induces death of pituitary tumour cells. Journal of Steroid Biochemistry and Molecular Biology 55 327-336.

Piston DW, Knobel SM, Postic C, Shelton KD \& Magnuson MA 1999 Adenovirus-mediated knockout of a conditional glucokinase gene in isolated pancreatic islets reveals an essential role for proximal metabolic coupling events in glucose-stimulated insulin secretion. Journal of Biological Chemistry 274 1000-1004.

Rabinowitz JE \& Samulski RJ 2000 Building a better vector: the manipulation of AAV virions. Virology 278 301-308.

Reid T, Galanis E, Abbruzzese J, Sze D, Andrews J, Romel L, Hatfield M, Rubin J \& Kirn D 2001 Intra-arterial administration of a replication-selective adenovirus (d11520) in patients with colorectal carcinoma metastatic to the liver: a phase I trial. Gene Therapy 8 1618-1626.

Riley DJ, Nikitin AU \& Lee WH 1996 Adenovirus-mediated retinoblastoma gene therapy suppress spontaneous pituitary melanotroph tumors in Rb+/- mice. Nature Medicine 2 1316-1321. 
Russell TA, Ito M, Yu RN, Martinson FA, Weiss J \& Jameson JL 2003 A murine model of autosomal dominant neurohypophyseal diabetes insipidus reveals progressive loss of vasopressin-producing neurons. Journal of Clinical Investigation 112 1697-1706.

Sato N, Wang S, Li L, Okabe K, Hashimoto M, Yaginuma H, Mikoshiba K, Uchiyama Y, Uetsuki T, Yoshikawa K et al. 1998a A novel strategy for introducing exogenous bcl-2 into neuronal cells: the Cre/loxP system-mediated activation of bcl-2 for preventing programmed cell death using recombinant adenoviruses. Molecular and Cellular Neurosciences 12 65-78.

Sato Y, Tanaka K, Lee G, Kanegae Y, Sakai Y, Kaneko S, Nakabayashi H, Tamaoki T \& Saito I $1998 b$ Enhanced and specific gene expression via tissue-specific production of Cre recombinase using adenovirus vector. Biochemical and Biophysical Research Communications 244 455-462.

Schiedner G, Morral N, Parks RJ, Wu Y, Koopmans SC, Langston C, Graham FL, Beaudet AL \& Kochanek S 1998 Genomic DNA transfer with a high-capacity adenovirus vector results in improved in vivo gene expression and decreased toxicity. Nature Genetics $\mathbf{1 8}$ 180-183.

Schlechte JA 1997 Differential diagnosis and management of hyperprolactinemia. In Disease of the pituitary. Diagnosis and treatment, edn 1, pp 71-77. Ed. ME Wierman. Totowa: Humana Press Inc.

Schwarzenberger P, Spence SE, Gooya JM, Michiel D, Curiel DT, Ruscetti FW \& Keller JR 1996 Targeted gene transfer to human hematopoietic progenitor cell lines through the c-kit receptor. Blood $87472-478$.

Shupnik MA, Pitt LK, Soh AY, Anderson A, Lopes MB \& Laws ER Jr 1998 Selective expression of estrogen receptor alpha and beta isoforms in human pituitary tumors. Journal of Clinical Endocrinology and Metabolism 83 3965-3972.

Smith-Arica JR, Williams JC, Stone D, Smith J, Lowenstein PR \& Castro MG 2001 Switching on and off transgene expression within lactotrophic cells in the anterior pituitary gland in vivo. Endocrinology 142 2521-2532.

Southgate TD, Windeatt S, Smith-Arica J, Gerdes CA, Perone MJ, Morris I, Davis JR, Klatzmann D, Lowenstein PR \& Castro MG 2000 Transcriptional targeting to anterior pituitary lactotrophic cells using recombinant adenovirus vectors in vitro and in vivo in normal and estrogen/sulpiride-induced hyperplastic anterior pituitaries. Endocrinology 141 3493-3505.

Southgate TD, Stone D, Williams JC, Lowenstein PR \& Castro MG 2001 Long-term transgene expression within the anterior pituitary gland in situ: impact on circulating hormone levels, cellular and antibody-mediated immune responses. Endocrinology 142 464-476.

Stec DE, Davisson RL, Haskell RE, Davidson BL \& Sigmund CD 1999 Efficient liver-specific deletion of a floxed human angiotensinogen transgene by adenoviral delicery of cre recombinase in vivo. Journal of Biological Chemistry 274 21285-21290.

Vecil GG \& Lang FF 2003 Clinical trials of adenoviruses in brain tumors: a review of Ad-p53 and oncolytic adenoviruses. Journal of Neurooncology 65 237-246.

Wickham TJ, Carrion ME \& Kovesdi I 1995 Targeting of adenovirus penton base to new receptors through replacement of its RGD motif with other receptor-specific peptide motifs. Gene Therapy 2 750-756.

Wickham TJ, Tzeng E, Shears LL, Roelvink PW, Li Y, Lee GM, Brough DE, Lizonova A \& Kovesdi I 1997 Increased in vitro and in vivo gene transfer by adenovirus vectors containing chimeric fiber proteins. Journal of Virology 71 8221-8229.

Williams JC, Stone D, Smith-Arica JR, Morris ID, Lowenstein PR \& Castro MG 2001 Regulated, adenovirus-mediated delivery of tyrosine hydroxylase suppresses growth of estrogen-induced pituitary prolactinomas. Molecular Therapy 4 593-602.

Windeatt S, Southgate TD, Dewey RA, Bolognani F, Perone MJ, Larregina AT, Maleniak TC, Morris ID, Goya RG, Klatzmann D et al. 2000 Adenovirus-mediated herpes simplex virus type-1 thymidine kinase gene therapy suppresses oestrogen-induced pituitary prolactinomas. Journal of Clinical Endocrinology and Metabolism 85 1296-1305.

Wyatt D 2004 Lessons from the national cooperative growth study. European Journal of Endocrinology 151 Suppl 55-59.

Zufferey R, Dull T, Mandel RJ, Bukovsky A, Quiroz D, Naldini L \& Trono D 1998 Self-inactivating lentivirus vector for safe and efficient in vivo gene delivery. Journal of Virology 72 9873-9880.

Received 7 October 2004

Accepted 8 November 2004 